\title{
僻地小児の思春期発育と栄養摂取量に関する研究 \\ Studies on Growth at Adolescence and the Protein and Calory Intakes of Children in a Remote Country
}

（昭 和 44 年 3 月 12 日 受 理）

\author{
中川 一 郎* 正 名 洋 子* \\ (Itsiro Nakagawa) (Youko Masana)
}

\begin{abstract}
Growth and nutritional status at adolescence of the children in a remote country were studied and compared with those of the children in the urban-, the rural-and the seaside-district, previously studied by the authors. Growth was discussed from the anthropometric (body height and weight) and the biochemical (creatinine and 17-ketosteroids in the 24 hour urine, and alkaline phosphatase in the blood serum) viewpoint. Besides, a survey of the intake of protein and calory was carried out in consecutive 3 days.

As results, the selection and intake for diets of the people in the so-called remote country are going to get nearer to those in the urban district, by reflecting an improvement in the traffic and the food situation. Therefore, pubertal spurt in growth of the children in a remote country was ascerelated in an early stage, and an aspect of growth of them is coming to be alike to that of the urban children.
\end{abstract}

さきに著者らは都市, 農村扎よび海岸地区小児の思春 期発育について, 形態的および生化学的な面から研究を

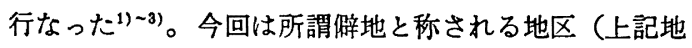
区と同様山形県下にある）における小児について前述地 区の小児の発育と対比するために同じ季節に，同じ項目 について調査および実測を行なった。

\section{研究方法}

昭和 42 年 10 月山形県最上郡堀内村小, 中学校（僻地 1 級) および鮭川村曲川小学校本校(僻地 2 級), 芦沢分校 (3 級)，木の根坂分校（5 級）の児童, 生徒について身
長,体重の計測, 24時間尿中クレアチニン4) 扰よび17-ケ トステロイド量(5), 血清アルカリフォスファターゼ値(3) の測定, さらにタンパク値扰よび熱量摂取量の連続 3 日 間にわたる調査を行なった。 研究結果

得られた結果は第 1 表の如くである。

身長, 体重について同じく僻地でも女児では鮭川は堀 内のそれに比べやや劣るが男児ではむしろ大きい。また これを 3 年前同じ県内にある左沢の農村の小児について 得た結果と比べると男では堀内は劣るが觟川の方は大で

第 1 表 僻地小児の形態的および生化学的数値

\begin{tabular}{l}
\hline \\
\hline
\end{tabular}

\footnotetext{
* 国立公采衛生院 栄盖生化学部
} 
第 2 表 僻地小児のタンパク質および熱量摂取量

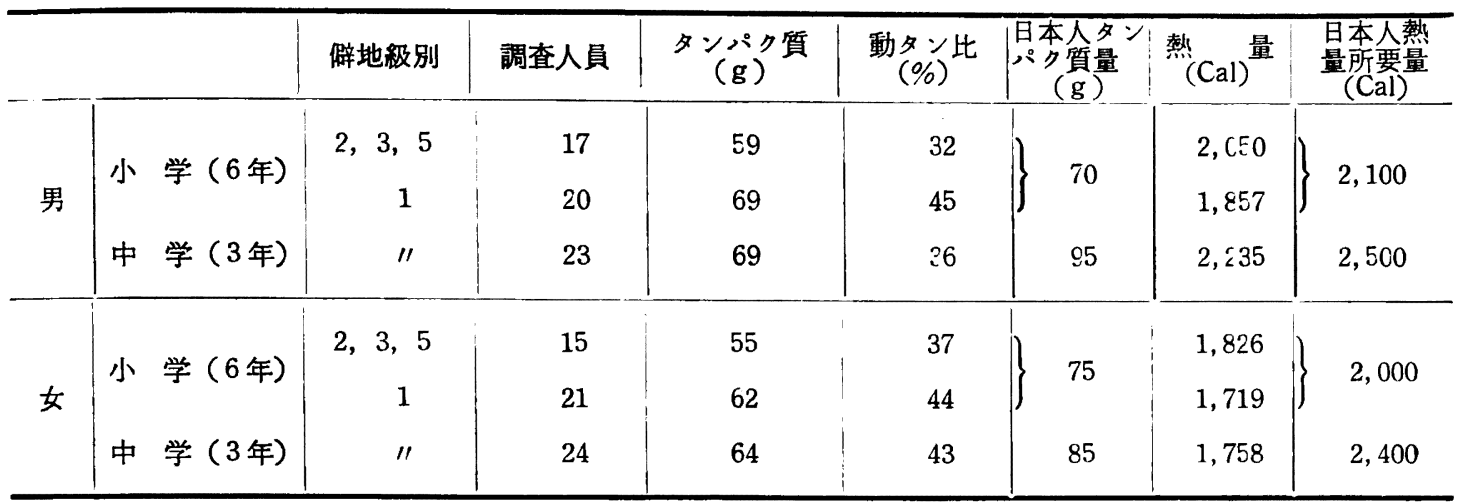

あり，女では左沢に比べすべて少る。都市の小児に比べ るとすちろんすへて遅れている。中学生では 3 年前の左 沢のそれより大であるが都市のそれより劣っている。な お, 初経来潮は平均13才 4 ケ月で都市小児のそれ（12： 6) よりおそいが左沢の当時のそれ(12:9)より早い。 クレアチニン排出量は小学生で堀内の方が觟川よりや や大であるが左沢のそれよりいずれる小である。17-ケ トステロイドは堀内のみについて行なったが左沢より大 で都市小児のそれと違いがなかった。アルカリフォスフ アターゼは堀内のそれは都市のより小であるが当時の左 沢のそれより大であり，鮭川のそれが左沢の值と大体同 じであった。このことは都市小児よりはすちろん, 堀内の それよりも骨発育の思春期促進開始の時期のおくれによ るすのと思われる。中学生では男児は都市, 左沢に比べ まだ高値を示したが, 女児では都市,左沢の中間値を示し 初経来潮の程度と比例していた。な拉，同じ觟川村での 僻地の程度による以上の項目についての比較は行なわな かった。これは級別にすると木の根坂では男, 女合わせ て 6 年生は 4 名に過ぎず比較の対象にならなかった。

食慨調査の結果(第 2 表)についてはタンパク質量およ び動タン比では觟川は堀内に少るが捸取熱量ではむしろ まさっていた。なお, 熱量, タンパク質量共に小学児童で は鮭川, 堀内共に都市はもちろん, 左沢よりも劣ってい たが動タン比では堀内は左沢より大でむしろ都市よりも 大きく漁村地方のそれと同じであった。中学では熱量摂 取量は男児では都市, 海岸生徒よりも劣るが, 左沢のそ れと同じであり，女児ではいずれに比べても劣っていた。

要するに形態的および生化学的な面からの地域差が漸 次なくなって来たことは僻地といわれる所る今日では交 通事情や経済状態の好転を反映して（たと党ば僻地 5 級
の木の根双では戸数18のうちテレビ18台, 自動車 4 台, オートパイ15台, ステレオ 2 台, 洗たく器13台, 冬季は 部落の大部分の男子が都市に出稼せぎに行く），食事摂 取の状態が都市のそれに近づきそのために思春期発有の 開始の時斯も都市のそれに近づきつつある事によるもの と思われる。

$$
\text { 結論 }
$$

いわゆる僻地と称される地区の小児の思春期発育と栄 養摂取の状況をしらべた。これをさきに報告した都市， 農村, 海岸地区の小児のそれと対比した。すなわち山 形県最上郡の僻地小, 中学校（僻地 $1,2,3,5$ 級） の児童, 生徒につき身長, 体重の計測, 24時間尿中クレフ チニン, 17ーケトステロイド, 血清アルカリフォスファタ 一ゼの測定，さらにタンパク質扣よび熱量摂取量の連続 3 日間にわたる調査を行なった。これらの測定各項目に ついて考察すると僻地といわれる地域す今日では交通事 情や経済状態の好転を反映して食慨撕取の状態は都市の それに近つき思春期発育開始の遅れは今なおあるとはい え，漸次都市のそれに近づきつつあることを知った。

$$
\text { 文献 }
$$

1）中川, 高橋, 小林, 正名, 大木 : 栄養と食糧, 18, 52 (1965)

2) 中川, 高橋, 小林, 正名, 大木 : 小児保健研究, 24, 16 (1966)

3）中川, 正名, 高橋：栄着と食糧 20, 181 (1967)

4) Peters, J. H., : J. Biol Chem., 164, 321 (1946)

5) 高橋: 末発表

6) Bessey, O. A. et al.: J. Biol Chem., 164, 321 (1946) 